Marjan SVETLIČIČ*

\title{
COVID-19: THE CHILD OF GLOBALISATION OR THE MOTHER OF DE-GLOBALISATION?
}

\begin{abstract}
The objective of the article was to evaluate the relationship between the Covid-19 pandemic and globalisation (GLO) and de-globalisation (de-GLO) tendencies. Based on a theoretical evaluation of this relationship as well as historical development, it concludes that Covid-19 is not the mother of de-GLO but its child, born in a completely new global context facilitating the pandemic. The roots of the pandemic's conception are more deeply embedded in the capitalist system, in its principal elements (market system, consumerist development model...). GLO as a global division of labour is not over; the factors enhancing GLO are winning over those slowing it down, provided that GLO becomes more egalitarian and more human. A fully-fledged de-GLO would be inefficient and painful. While the pandemic is not a black swan, it could have been predicted. Such an unprecedented crisis impersonated by the pandemic also offers an opportunity to fundamentally rethink of our theories, way of life and development paradigm and, not the least, the whole system to be better prepared for future similar crises.
\end{abstract}

Keywords: Globalisation, de-globalisation, Covid-19, development model, anthropocentrism, system, history of GLO, future of GLO, post pandemic

\section{Introduction}

The Covid-19 pandemic arrived when the world was already faced with an unprecedentedly complex set of challenges/crises that had long been accumulating. The virus has brought to the surface already simmering problems, exposing and exacerbating long-neglected problems that are turning into major crises. These include: an environmental crisis, huge Slovenia.

Marjan Svetličič, PhD, Professor Emeritus, Faculty of Social Sciences, University of Ljubljana, DOI: $10.51936 /$ tip. $58.3 .860-881$ 
income inequality ${ }^{1}$, migration/refugee crisis and a humanitarian crisis as a consequence, food and water insecurity, technological advances but also a slowdown in productivity ${ }^{2}$, the erosion of democracy, digital (dis)information and erosion of privacy, ageing populations, a GLO backlash, economic nationalism (EN) and protectionism, trade wars, tectonic changes in the world power structure and, finally, increasing public debt (due to the extensive rescue packages introduced by most governments). The pandemic can be contained (vaccination, immunisation) and the situation normalised. Yet, we cannot recreate the environment or the climate, or re-establish ecological sustainability overnight, let alone restore the trust lost after so many "apocalyptic visions, cults, and new religions growing up around the extreme anxieties caused by prolonged hardship" (Fukuyama, 2020). Not surprisingly, it was argued in a recent UN Security Council debate that "without quick global collective action, climate change could well prove to be the slow-motion version of the coronavirus outbreak reshaping economic, political and security conditions around the world in negative ways" (van de Pas, 2020: 20). "Given the spread of the pandemic and transmission pattern, one could argue that Covid-19 started as an infectious 'disease of affluence', in contrast to the "disease of poverty" (supra, 2020: 7).

Later, the socio-economic dimension became the most challenging one in terms of both the economic downturn and the anti-virus restrictions due to the prioritising of health over economic activity. The radical uncertainty and turbulent conditions suggest the virus is making the world non-ergodic (whereby processes change erratically at inconsistent speeds), implying that a system will not return to states closely similar to earlier ones (Buckley, 2020: 1582). The situation is wicked in nature because it cannot be solved by applying rational-scientific methods (Eden and Wagstaff, 2020: 3), but requires new policies and capabilities for a radical, non-ergodic, wicked world ${ }^{3}$ characterised by radical uncertainty (Raškovič, 2021), in a VUCA (vulnerability, uncertainty, complexity and ambiguity) world or, according to Beck (1999), a risk society. The pandemic has merely added to these huge problems. "Now, firms and nations alike are discovering just how vulnerable they are" (Farrell and Newman, 2020), how fragile our world is.

1 Mainly within countries, while inequality between them has, thanks to the rise of China, been decreasing. Less developed countries (LDCs) will be hit the most (poor health systems and standards, later access to vaccines).

2 Labour productivity growth has fallen in most economies over the past two decades even while large advances have been made in technology (NIC, 2021: 41). Total factor productivity has slowed less.

3 Churchman refer to wicked problems as "that class of social system problems which are ill-formulated, where the information is confusing, where there are many clients and decision makers with conflicting values, and where the ramifications in the whole system are thoroughly confusing" (1967: B-141). 
Crises are not new phenomena, but this time it is different. First, because it is the accumulation of several multifaceted crises all at once not seen thus far in history and, second, their enormous dimensions. Our way of life has been disturbed. The relative importance of priorities has been disrupted. Health security and resilience ${ }^{4}$ have become more important. The pandemic has been a powerful reminder of the weaknesses of our warning systems and lack of preparedness for handling future, sudden or long-lasting, deeply-rooted crises. This means that a shift in our mind-sets, theories and policies is needed.

This health crisis is awkwardly unfolding at a time when the world is increasingly thrown off kilter by growing nationalistic and isolationist tendencies. Just look at "Brexit, increasing tensions within the EU, fissures within NATO, a growing contraction in world trade, erection of border fences to stem illegal immigration" (Pross, 2020: 1). It is apparent that we have not learned the lesson of the Great Depression (GD) of 1929 when a myopic spiral of nationalistic tariff-retaliation responses created a disaster. 'Beggar thy neighbour' policies have turned out to be 'beggar thyself' policies.

Heated debates started among those claiming that "globalisation in its current form has reached its limits" (De Grauwe, 2016) and that we are 862 facing the end of globalisation (Young, 2020), and those claiming that it is only a short "episode" in its further development. Many believe GLO is to be blamed for the spread of the Covid-19 virus right around the world. Globalisation backlash and de-GLO tendencies, including glocalisation, have started to accelerate, with the Covid-19 crisis only adding to this GLO backlash. Debates similar to those in the early years of GLO, blaming GLO for all of the ills of society, emerged ${ }^{5}$. It is therefore high time to look at the relationship between Covid-19 and GLO, between GLO and de-GLO, so as not to fall into Fukuyama's trap of prematurely declaring the end of GLO, like he did for history.

All crises, including the pandemic, are both a huge problem and an opportunity not to be 'bundled away', and can be Plato's "necessity as the mother of invention". It may prove to be a turning point in the development of humankind. It is encouraging that "as damaging as the crisis has been, the rapid adoption of stimulus packages of unprecedented magnitude demonstrates that, when necessary and where possible, governments are capable of taking courageous steps and intervening on a massive scale" (UN, 2020: 6), more following Keynes' and not M. Friedman's recipes.

4 This is mostly a psychological concept referring to individual resilience, making individuals less vulnerable to external unexpected events, but is less of a collective one. Now, we must also talk of the resilience of a group, country, region or individual. Darkow (2018) also distinguishes proactive from reactive resilience.

5 Svetličič, 1997 and 2000 . 
The main questions addressed in this article are:

a. Is Covid-19 a black swan or a predictable unpredictability?

b. Is GLO responsible for the Covid-19 pandemic and thus the last nail in GLO's coffin or is it a solution to the pandemic?

c. Will the factors enhancing GLO win over those slowing it down?

d. Is the context enhancing or slowing GLO down?

e. Is the Covid-19 crisis an opportunity for fundamental, systemic changes?

\section{The characteristics of Covid-19}

Covid-19 was unexpected, although it should not have been because many studies had predicted ${ }^{6}$ that such a pandemic is a possible "black elephant", "an unlikely, unexpected event with enormous ramifications and the 'elephant in the room', a problem that is visible to everyone, yet no one still wants to address it even though we know that one day it will have vast, black-swan-like consequences" (T. Friedman, 2014). The big issues are therefore why we were unable to see the pandemic coming, and whether the crisis could have been prevented.

While the pandemic is a considerable threat, it should not act to blind us with respect to even more serious long-term crises. They all coincide as:

four crises: a health, an economic, a social and an ecological/climate crisis. COVID-19 is just additionally exacerbating the previous crises. Solving one crisis without taking the others into account would just mean passing the problems to the next generation and not create healthier planet now. (Mazzucato, 2020)

The 'depreciation' of natural capital (for example, through the damage done to ecosystems) is often irreversible/.... /The world now confronts the rising risk of transmitting zoonotic viruses such as COVID-19, largely due to human induced environmental change such as forest cover conversion, and increased interactions between human settlements and nature. (UN, 2020: 7)

Such crises are in-built in the capitalist system, revealing its fragility, deficiencies, even biological pathologies ${ }^{7}$ and injustices. We have seen crises in the past, and also will in the future, depending on the extent to which countries are integrated into the global system, the production networks.

6 Van Pas, 2020.

7 "Such biological shocks have been destroying empires, overthrowing economies, decimating entire populations. When they spark or coincide with other crises they mark moments of transformation or redirection in the stream of history" (Harper, 2020). 
Countries with greater socio-economic GLO are more exposed to COVID-19. Nevertheless, GLO is unable to explain cross-country differences concerning the impact of COVID-19 because they also depend on the socio-economic institutions of the countries concerned, like cross-country variation in health infrastructures and demographic structures (Farzanegan et al., 2020).

\section{Theoretical framework}

The intersection of the pandemic with GLO demands a multidisciplinary approach. Since GLO refers to the free movement of goods, services, capital and people across borders, any initial theoretical framework must include theories that explain such movement. Ones that clearly contend that foreign trade, leading to specialisation, innovation, the enhancing of comparative advantages, efficiency and stimulate growth ${ }^{8}$ is a win-win, 'first-best' solution. The size of internal markets limits the reach of specialisation and the division of labour. This means GLO might be the most optimal framework for the division of labour. Theory has downplayed both the fact that international trade involves winners and losers as well as the relevance of trade policy. The debate on the distribution of the costs and benefits of inter-country

864 trade has surfaced now since the emerging economies, primarily China, are taking an ever-bigger share of the international trade pie.

Theories of crises cover the other side of the GLO-pandemic equation. Malthus was first to talk about a theory of crises, followed by Marx, in the context of the contradictions of capitalism. Crises were viewed as "an inherent inbuilt feature of capitalism" (Ferguson, 2002; Kindleberger, 1989). Roubini and Mihm (2010: 211) labelled them part of the very "capitalism genome". According to Kondratieff (1935), their cyclicality is closely related to technological disruptions in society. For Schumpeter, creative destruction is the best instrument for exiting crises (1934).

Crises are a very complex, multidisciplinary problem capturable by the heuristic international political economy. Hyper GLO has clearly catapulted the political economy trilemma (trade-offs) of sovereignty ${ }^{9}$, GLO and democracy or the inability to have all three at the same time (Rodrik, 2011). Accordingly, reconstructing the global economy in a post-pandemic world cannot rely on old formulas and it is hard to theoretically generalise. It is easier to rely on abductive reasoning and to make a conclusion based on the limited information we know about complex phenomena, leading to the most logical, yet not generalised conclusions.

8 Adam Smith (1776/199: 1-5) believed that the productive power of labour, of specialisation, and of the invention of machines increased when one worker specialises in one type of activity and trades with other specialised workers.

9 Or autonomy as elaborated on by Rizman (2008). 
The political science approach shows how "the political system was highly significant in both the 1930s and 2000s crises with opposite impacts. In the 1930s, autocratic rule and dictatorship were associated with stronger deGLO; in the 2000s, democracy is associated with stronger de-GLO (Bergeijk, 2010: 62). The Covid-19 crisis bears greater similarity with the episode of the GD due to autocratic tendencies threatening democracies around the world, including in former bastions of democracy, like the USA. This contradicts the general theoretical assumption that democratic countries tend to have more liberal trade policies, that social and economic stability is correlated with openness, egalitarianism, tolerance and democracy. Trump's economic nationalism (America First), later spreading to other democracies ${ }^{10}$, questions such assumptions. To solve problems of this nature, shortcuts are sought for salvation in the form of powerful personalities, in authoritarianism hating the weak (fascism), and the use/abuse of democratic institutions to achieve their goals. They might be flourishing because democracies ignore or underestimate such tendencies, like what occurred during Hitler's rise to power.

International relations theories also help to explain the GLO-de-GLO dilemma. Witt's de-GLO framework builds on the contrast between a liberalist and realist theoretical view of de-GLO in terms of transnational economic and political interconnectedness. Liberals stress complex interdependence and international cooperation that make wars less feasible because the fortunes of all are so highly interconnected. However, actors' changing interests or ineffective institutions may lead to changed interests that also allow de-GLO factors to be enhanced. On the other hand, "according to a realist perspective, de-GLO is caused by 'hegemonic decline' and loss of power" (Witt, 2019: 1059).

\section{Context matters}

The major characteristics of today's global context that is shaping a completely new environment are:

a. the interlinked and ever more interdependent world;

b. the capitalist system and crisis of the consumer model;

c. the synchronisation of business cycles;

d. tectonic changes with shifts in the power structure and the decline of multilateralism;

e. the slowing down of GLO;

10 "The election of Trump, Brexit and the Netherlands referendum against the EU corroborate this finding for the 2000s" (Bergeijk, 2010: 68). Populism is thus strongly correlated with the major problems of contemporary capitalism: GLO, insecurity, uncertainty with all the psychological consequences like frustration, fear, anxiety and outrage of the (non-rich) population. 
f. the VUCA environment in the enhanced digital world; and

g. populism, eroding democracies, and greater anomia. ${ }^{11}$

The failure of many theories is not haven taken this new context sufficiently into account. "The contextualization of existing theories is important in order to overcome prevalent contextual parochialism of Western Paradigms" (Boyacigiller and Adler, 1991) as is testing their relevance in different contexts because there is no one size fits all theory or development. Years ago, Polanyi was clear when stating that "the economy has always been embedded in society, and, when we try to dissembled it from society and treat it like an independent institution - i.e. not dependent on societies, values and other institutions - then we're really going to run into trouble, political conflict, social and economic instability and some kind of backlash. If we lose track of that, we risk another set of instabilities and an eventual collapse of GLO" (Rodrik, 2020b).

The world now is more complex and borderless, more interdependent and pluralistic, yet paradoxically it is a more fragmented, ${ }^{12}$ non-ergoic world of wicked problems. A massive shift in economic power is underway, shifting the centre of gravity to Asia with China becoming the leading global 866 player.

The result of greater $\mathrm{GLO}^{13}$ is an increase in the synchronisation of economic cycles (IMF, 2007) and real-time correlation. Butterfly effects occur almost simultaneously. The much stronger global integration via global value chains $\left(\mathrm{GVCs}^{14}\right)$ has added to the level of countries' integration.

What really makes this era of history fundamentally different from any other in modern history - and by that I mean the last few hundred years - is the importance of global issues: climate, terrorism, infectious disease, a nonregulated cyberspace, proliferation of trade and investment. The flows are so fundamental, and for better and for worse, that's qualitatively different than what we've seen historically in terms of the number of issues and their power and importance. (Haass, 2020)

\footnotetext{
11 Normlessness society, the breaking down of moral values, standards, or guidance for individuals to follow. It may evolve from the conflict of belief systems and causes the breakdown of social bonds between an individual and the community (both economic and primary socialisation).

12 "This encompasses rising tensions, division, and competition in societies, states, and at the international level. Many societies are increasingly divided among identity affiliations and at risk of greater fracturing" (NIC, 2021: 3).

13 What really makes a difference to previous GLO eras is the unprecedented mobility of everything. goods, services, capital, people and all other related things like environmental damage, climate disasters.

${ }^{14}$ They represent up to $60 \%$ of global trade (UNCTAD, 2013).
} 


\section{GLO and Covid-19}

GLO has a Janus face ${ }^{15}$, at once ugly and nice; a double-edged sword. On the bright side, it has, albeit very unequally, increased world wealth and welfare (health longevity, child mortality, education, improvement of health and education ${ }^{16}$ ). Yet GLO also has a darker side, having contributed to huge inequality, environmental damage and climate change while accelerating the possibilities of crises.

The supporters of GLO argue the benefits outweigh the drawbacks ${ }^{17}$, while critics wish to either improve the conditions of global trade or, in some cases, roll GLO back. Some see GLO like a Tsunami sweeping across the planet or like a snow avalanche: while it cannot be stopped, one can swim to rise to the top, in the hope of staying alive. The big issue is that the losers of international trade have not been adequately compensated by the redistribution policies, either by national welfare systems or internationally. It was initially considered that such losers are small compared to the winners, yet in fact they are much more common and also include those not expected early on to be the losers: the middle class in developing countries (LDCs) (Lakner-Milanovič's elephant curve, 2013). The mood has changed ever since the GR also hurt the middle class in developed countries (DCs), and particularly during the pandemic. GLO, frequently impersonated by China's expansion, has started to become a scapegoat for the pandemic and inequality. The GLO backlash started with the rise of protectionism ${ }^{18}$ and populism (targeting foreigners/migration as the cause of local troubles, inequality, lower wages).

The results of GLO depend on man-made policies. For some, the pandemic is also a crisis that will bring about a fundamental change on the global 'economics and politics' chessboard. For others, the basic principles of the international order are likely to remain much the same. The first step in accommodating such bipolar views is to look for historical lessons.

15 Such ambivalence, or even a dialectic phenomenon, producing divergent, or even contrary effects, is not only specific to GLO but to the majority of socio-economic phenomena.

${ }^{16}$ Consider the impressive improvements in fertility rates, infant death (that halved between 19602020) and secondary education that tripled in the same period (NIC, 2021:20).

17 But there was no convergence among countries as some optimists had predicted, although inequalities among countries have decreased (the effect of China).

18 The protectionist arguments have recently (paradoxically) been advocated by the right (historically more by the left), calling to restrict the free flow of labour and capital across borders. 


\section{History lessons}

GLO cannot be understood simply in terms of contemporary evidence because GLO started well before capitalism. A common denominator of all early stages of GLO was their cosmopolite nature, a characteristic of all "innovative and dynamic societies" (Bourguignon et al., 2002: 2). Second, they were all backed by certain political/military power ${ }^{19}$ and competition among the great powers, like we also see today. As these configurations change, the type of economic GLO also changes (Findlay and O'Rourke, 2007). The tectonic changes now underway in the global economy are a manifestation of such a rebalancing of world power.

Historian Williamson (2002) divided modern GLO into four epochs:

Epoch I Anti-Global Mercantilist Restriction 1492-1820

Epoch II The First Global Century 1820-1913 with the Gold Standard (1870-1913)

Epoch III Anti-Global Retreat 1913-1950 or "interwar GLO retreats" (Bordo et al. 2003)

Epoch IV The Second Global Century 1950-2002 (the convergence of DCs and the first East Asian miracle, later China's fast growth and after the fall of the Berlin Wall (1989) when former socialist countries joined in the GLO process

The world economy's history may thus be described as 'waves of GLO'. Two of the GLO epochs entail GLO expansion and two de-GLO eras. All of these GLO and de-GLO (and even the much earlier golden stages of GLO) epochs led to a more open world and stimulated the rapid growth of scientific knowledge, technological innovation, and economic productivity. Still, openness supported convergence only in certain countries and circles, giving "little reason to be confident that opening doors to the world economy will guarantee a place at the high table" (Bordo et al., 2003: 217, 218).

The third characteristic was that GLO has not been evolving linearly and is not irreversible or even inevitable as some mythical approaches to GLO assume. Particular major events like wars or very offensive protectionism (as in the GD) has and can derail GLO, "because human beings are able to cooperate harmoniously also in order to kill each other" (Norberg, 2020) in destructive wars. For instance, the first modern era of GLO ended badly with World War I (WWI) and later with World War II (WWII). The era of war was followed by the GD, the rise of protectionism and competing devaluations, later fascism yet also the New Deal. These were policy-induced, manmade crises that "led to the breakdown of the international political order

19 Early GLO was an extension of Britain's naval power and British imperialism while the Bretton Woods system was an extension of the USA's domination after WWII. 
and WWI. What worries is, that similar repeated backlash is in the works at present" (Bordo, 2017). External determinants of GLO like the major political or economic upheavals/wars, different types of large crises (including the climate one), but also smaller ones like the oil crisis (1973/1974) and the housing crash played a crucial role. Some determinants of such developments are internal, embodied in the GLO per se ("globalization has the seeds of its own destruction"; James, 2002: 6). The internal factor of GLO oscillations is the capitalist system with its in-built crises, financial or otherwise, as predicted by Marx and Kondradiev.

History leads us to the conclusion that Covid-19, as an external factor, or the environmental crisis, climate change, migration, the crises of democracies, and the resulting health and social crises will certainly put considerable sand in the gears of GLO (international trade, FDI, and already contracting GVCs) ${ }^{20}$, but, according to theory, will not completely halt it.

On the other hand, Keynes' very appealing, in fact, anti-GLO, statement might appear unrealistic:

I sympathize, therefore, with those who would minimize, rather than with those who would maximize, economic entanglement among nations. Ideas, knowledge, science, hospitality, travel - these are the things which should of their nature be international. But let goods be homespun whenever it is reasonably and conveniently possible, and, above all, let finance be primarily national (Keynes, 1933).

Delinking from the world economy, while politically very appealing, has proven in the past to be very costly ${ }^{21}$.

\section{The long-term pros and cons of GLO}

The first pro GLO factor is free trade and specialisation. The second is technological development, ${ }^{22}$ the modernisation of transport reducing the cost of distance and, recently, digitalisation. On the other hand, the most obvious anti GLO factor is the danger of war (often due to power rivalry; now between the USA and China) which in the past and possibly also in the future can substantially slow GLO down. The second set of con GLO factors

20 The flows of goods, services and finance contracted between 2007 and 2017 by 16\% (Mendoza et al., 2021: Figure 1).

${ }^{21}$ Like China's experience during the Ming Dynasty, withdrawing from its previous global expansion into itself and entering into a 200-year-long slump (Svetličič, 2020: 80).

22 Although technology has generally stimulated GLO, it can also de-stimulate it. For instance, "3D printing could wipe out $40 \%$ of international trade by 2040. Automation is leading to increase in the production and consequently more imports" (The Economist 2020, 19 Dec.: 100). 
are crises, the rising inequality and other GLO-related social problems that exacerbate the gaps between LDCs and DCs and conflicts among them. The trade-offs made between these factors will decide on GLO's future.

\section{Table 1: SUMMARY OF PRO AND CON GLO FACTORS AND POTENTIAL SOLUTIONS}

\begin{tabular}{|c|c|c|}
\hline Pro GLO drivers & Con GLO factors & Solutions \\
\hline $\begin{array}{l}\text { Benefits of free trade and } \\
\text { specialisation }\end{array}$ & Increasing inequalities & $\begin{array}{l}\text { Reshaping of GLO to new, } \\
\text { more human*, } \\
\text { empowering redistribution } \\
\text { policies }\end{array}$ \\
\hline $\begin{array}{l}\text { Hyper globalisation also } \\
\text { leading to irrational GLO } \\
\text { Biologically unsustainable } \\
\text { globalisation }\end{array}$ & $\begin{array}{l}\text { GLO backlash } \\
\text { Economic nationalism, trade } \\
\text { wars } \\
\text { Rebellion against cultural } \\
\text { homogenisation } \\
\text { Glocalisation (production, } \\
\text { culture...) }\end{array}$ & $\begin{array}{l}\text { Reducing unreasonable, } \\
\text { unsustainable, redundant } \\
\text { GLO flows } \\
\text { Enhancing the circular } \\
\text { economy strategy }\end{array}$ \\
\hline $\begin{array}{l}\text { Interdependence, } \\
\text { interconnectedness }\end{array}$ & $\begin{array}{l}\text { Growing vulnerabilities, } \\
\text { uncertainties, erosion of } \\
\text { trust,** }^{* *} \\
\text { the VUCA world }\end{array}$ & $\begin{array}{l}\text { Building resilience } \\
\text { Reestablishment of trust } \\
\text { Improving capabilities for } \\
\text { anticipatory adjustments }\end{array}$ \\
\hline $\begin{array}{l}\text { Technologic/transport } \\
\text { advances } \\
\text { Urbanisation } \\
\text { Digitalisation } \\
\text { Virtualisation of } \\
\text { communications } \\
\end{array}$ & $\begin{array}{l}\text { Risks of systems' collapse } \\
\text { The pandemic (seen as a } \\
\text { result of GLO) } \\
\text { Cybercrime } \\
\text { Terrorism }\end{array}$ & $\begin{array}{l}\text { Improving safety nets, backup } \\
\text { systems, fighting cybercrime } \\
\text { New global governance (more } \\
\text { policy space for countries) }\end{array}$ \\
\hline $\begin{array}{l}\text { The global expansion is } \\
\text { rooted in capitalism as a } \\
\text { global system }\end{array}$ & $\begin{array}{l}\text { The systemic character of } \\
\text { crises, US-China rivalry for } \\
\text { global primacy; including } \\
\text { systemic competition } \\
\text { Political conflicts, even threats } \\
\text { of war }\end{array}$ & $\begin{array}{l}\text { Changing the capitalist system } \\
\text { Changing the consumer } \\
\text { anthropocentric model to } \\
\text { green civilisation*** } \\
\text { Creating an international } \\
\text { biosecurity strategy } \\
\text { 21st-century multilateralism }\end{array}$ \\
\hline $\begin{array}{l}\text { Enhancing growth } \\
\text { demand permanent } \\
\text { production and expanded } \\
\text { consumption }\end{array}$ & $\begin{array}{l}\text { The economic, environmental, } \\
\text { social and health crises } \\
\text { arising from the pandemic } \\
\text { are threatening the survival of } \\
\text { humankind }\end{array}$ & $\begin{array}{l}\text { Global problems demanding } \\
\text { global solutions } \\
\text { Strengthening the role and } \\
\text { influence of science } \\
\text { Closer scientific cooperation } \\
\text { to address fundamental global } \\
\text { problems }\end{array}$ \\
\hline
\end{tabular}

*Based on the principle of humanity (Bauer, 2008); **A long-lasting pandemic shock creates anxiety, people are afraid of each other (of becoming infected), trust is lost; ${ }^{* * *}$ The problem is whether it is possible to have green capitalism in a system where profit maximisation is the ultimate aim. These issues are to be addressed in a separate article.

Source: own analysis. 
The rebellion against the homogenisation of tastes, culture, against the cocacolaisation of the world, gave birth to a renaissance of national values, meaning that such homogenising does not necessarily destroy the local and the particular, or preclude diversity (Zelizer, 1999). The trade-off between GLO and de-GLO is hence also between GLO and regionalisation, concentration and fragmentation, between homogenisation and heterogenisation, between losing and retaining autonomy ${ }^{23}$. People are starting to value more "what is close to them which in a way is to safeguard for not losing one's identity" (Rizman, 2008: 23).

\section{The future of GLO. To globalise or not to de-globalise, is this the question?}

The purpose of this section is to consider the possible future of GLO following the Covid-19 pandemic. Second, how can we balance the con and pro GLO factors so as not to undermine the positive effects of GLO (rising productivity, less inefficiency). Finally, to see whether a hybrid version or synthesis of GLO and de-GLO is possible.

The first threat is the geopolitical, economic rebalancing between the hegemony of the USA and the growing China (Thucydides trap) which could pit the two countries against each other in dangerous rivalry (even a war), threatening to stop or slow GLO. This not only threatens GLO but also democracy that is ever more under attack from increasing illiberalism because the pandemic is, like other crises, a fruitful moment for authoritarianism to rise.

The pandemic crisis is the second big present threat to GLO by slowing it down, shortening, rationalising, localising, reshoring or nearshoring GVCs in order to reduce risk, dependency and vulnerability. The tendencies thus far show more of trend towards the regionalisation of sourcing, not its nationalisation. As a result, the impact on GLO might not be as vast as first expected.

Public attitudes might also act to slow GLO down. The public's initial reaction was to blame GLO and China for the pandemic. Yet the pandemic would have developed globally even without hyper GLO just more slowly like the Spanish flue or similar pandemics in the past. GLO merely facilitated its global spread in real time. Anti GLO attitudes are to some extent just the pinnacle of the mountain of anti GLO attitudes that have accumulated over time, especially now in Western countries that previously were advocating modern GLO, while originally it was LDCs who were opposed to GLO. Together with certain other Asian countries, China ${ }^{24}$ is becoming

\footnotetext{
23 GLO biggest sin is its superior role vs. autonomy (Rizman, 2008: 226).

24 Already in the 1980s, China was embracing GLO as its strongest development tool.
} 
an influential advocate of GLO and the existing world system ${ }^{25}$ that has benefited them so much ${ }^{26}$. Globalization became a scapegoat for the financial crisis, for immigration for the unemployment, although empirical research has shown convincingly that the influence of automatisation/robotisation was much stronger (Autor et al., 2013), also drove such changes in opinion.

\section{What then is globalisation future after the pandemic?}

The future of GLO depends first on factors propelling its long-term development and second on the external factors influencing it. The internal driving force of GLO is the global division of labour/specialisation it has established. Both drive productivity and increase wealth. Internationalisation, built into the capitalist system, was nicely described already in the Communist manifesto:

The need of a constantly expanding market for its products chases the bourgeoisie over the whole surface of the globe. It must nestle everywhere, settle everywhere, and establish connexions everywhere. The bourgeoisie has through its exploitation of the world-market given a cosmopolitan character to production and consumption in every country. (Marx and Engels, 2006/1928:12)

Edvard Kardelj, the Slovenian leading communist party ideologue, also viewed such an expansion as positive in certain conditions, stating that:

the process of integration of labour, of the means of production, and capital is a historic development. Under the conditions produced by contemporary technology, such labour integration is an irreversible and progressive component of the development of productive forces. /... $/$ But it will discharge this historical role only to the extent that it is rid of exploitative relations imposed by the monopoly capital and various systems of economic and political hegemony. (1979: 47-49)

Globalisation is hence a process filled with contradictions, the simultaneous presence of too much and too little GLO. Too much in terms of

25 80\% or more of respondents in Vietnam, the Philippines and India saw "GLO more as a force for good in the world". Respondents in 10 more countries supported it at the level of over 60\% (also including some small DCs (Denmark, Sweden) and Germany. France's position was on the other extreme, with an almost balance of supporters and opponents. In the USA, GLO was regarded as good by $40 \%$ of respondents (accessible at https://today.yougov.com/topics/politics/articles-reports/2016/11/17/international-survey).

26 They realised that "it doesn't matter whether a cat is white or black, as long as it catches mice?" (Deng Xiaoping). 
unnecessary trade ${ }^{27}$, cultural homogenisation, and too little in terms of solidarity, cooperation (especially in R\&D), the effectiveness of global governance for addressing new issues like inequalities, climate change, digitalisation, cybercrime etc. It is almost impossible to predict the result of this trade-off due to the simultaneity of both sets of drivers and their considerable context- and time-dependence. All of the long-term drivers are not only rooted economically (like the division of labour) but also affected by political forces ${ }^{28}$. Their strength varies over time as well.

The real question is "whether short-run forces will change the longrun dynamics of international capitalism" (Bordo, 2017: 12). Covid-19 is one such factor. What then is the right answer to such opposite opinions? Lamy $^{29}$ (2020) is clear indicating "that de-GLO is not the answer: The degree of interdependence means that it would be extremely costly. Globalisation is efficient and painful. De-GLO would be inefficient and painful.

But it is also highly unlikely that the world will return to the idea of the mutually beneficial GLO which defined the early 21st century (Niblett, 2020). Empirical evidence supports such views. Hillenbrand's in-depth analysis (2010: 1) demonstrated that:

if globalization halts or recedes the results will be profoundly negative for most countries ${ }^{30}$ and most income groups. While a retreat into protectionism may improve income equality in some countries, it will reduce incomes of both the poor and the rich and poverty headcounts will be increased. In addition, political instability will rise in a majority of countries and the probability of interstate war will increase. / ... The likelihood of state failure through internal war, projected to diminish through 2035 with increasing globalization, rises in the deglobalization scenario particularly among the non-OECD democracies. Similarly, deglobalization makes for more fractious relations among states and the probability for interstate war rises. (2010: 5)

Still, this does not mean that GLO as we know it today can proceed unchanged. On the contrary. "The erosion of US power going into a multipolar global system renders fundamentally impossible the type of economic

27 Some goods are too pollution-intensive to be transported globally. Others are like "the export of milk from Italy to Germany to be processed there into yogurt and then to Brindisi, from where it goes to Greece to make feta to be sold back to Germany", posited Mencinger (2010). UNCTAD estimated that around onequarter of intermediate goods re-cross borders at least twice before final assembly (2013).

28 Political shocks can have either negative (the election of Donald Trump and Brexit) or positive effects (the election of J. Biden in the USA, for instance).

29 For 8 years, he was the Director-General of the World Trade Organization (WTO).

30 The only winners are a small number of countries that were small and poor and not well integrated into the global economy. The gains from de-GLO are very small, even for them (ibid., 2010: 14). 
globalization we've had in the past few decades. So we need to think of a new kind of GLO that is going to be underpinned by a multi-polar system, a much more heterogeneous configuration of political power at the global level" (Rodrik, 2020b). Of course, the existing system has many holes but is much better than protectionism, every country-first policies leading to chaos in international (economic) relations in the absence of the rule of law. A major challenge is thus to design a new system of global governance which narrows the gap between the global character of problems (crises, the pandemic, GLO...) and their governance that has chiefly been nationbased in a state-centric global community.

Presently, we see that COVID-19 is stimulating a world that is less open, less prosperous and less free. We are now more in a "return to a more deglobalized era" (Kobrin, 2017). Vaccine nationalism, restrictions on exports of masks for instance, the beggar-thy-neighbour or even 'sickening thy neighbour' type of protectionism in general and a policy of blaming others ${ }^{31}$ have spread far and wide. Simultaneously, countries became more open to coordinating health and $R \& D$ policies with a view to developing a vaccine. The recent crisis shows how neither science nor technology can succeed without GLO since "all of these threats are global, and common to all human-

874 ity, and can be lastingly reduced only by global cooperative action" (Posen, 2020).

"The Covid-19 pandemic will not fundamentally alter global economic directions but only accelerate a change that had already begun: a move away from US-centric globalisation to a more China-centric globalisation" (Mahbubani, 2020). "This crisis will reshuffle the international power structure in ways we can only begin to imagine" (Haass, 2020). Milanović agrees, claiming that the "pandemic will not be an end of globalization" (2020). Globalisation could even develop new, yet different impulses; the actual mobility of labour might be substituted by virtual labour and so might many other services and trade in goods. "The post pandemic world is likely to need, and witness, even more globalization" (Contractor, 2021) of a different kind and in all other areas (we can add).

\section{Conclusion}

The first general conclusion of our study is that the Covid-19 pandemic is not the mother of de-GLO, but its child. It facilitated the pandemic, but did not give birth to it. The pandemic's conception is more deeply rooted in the capitalist system and its biggest elements (market system). The second

31 While putting all the blame on China, calling the virus the Chinese virus, Trump forgets that the GD in the 1930 s and the GR of 2008 might be labelled American because the USA exported them both. 
conclusion, based on as a global division of labour/specialisation, is that GLO is not over. Throwing the baby (GLO) out with the bathwater (virus) while dreaming of a return to autarky is no answer. A fully-fledged de-GLO would be inefficient and painful because, by throwing away the advantages of the division of labour, everybody would lose out. Still, GLO must be transformed and become more egalitarian, more human.

More specific answers to our major research questions are:

In relation to a): Covid-19 is not a black swan, but a predictable unpredictability/uncertainty. The problem is that such warnings have been ignored, partly out of ignorance and partly because they did not fit with the existing profit maximisation, consumerist, anthropocentric development paradigm. Our reaction was more like a black elephant.

In relation to b): GLO is not responsible for the Covid-19 pandemic, but it did provide the infrastructure for the virus to spread around the globe. The Covid-19 pandemic only brought to the surface and accelerated deeplyrooted problems in the capitalist, Darwinist winners-take-all system, ignoring most of humankind's long-term detrimental effects on nature, on our environment. This created a 'market' in which to develop and spread viruses. This means the pandemic cannot be the final nail in the coffin of GLO, but is instead just another in-built systemic factor. The pandemic could help "put to rest the extreme forms of neoliberalism" (Fukuyama, 2020). More intensive international scientific and policy cooperation has already proven to be a solution for containing the pandemic. Consequently, even more intensive global cooperation/GLO is needed.

In relation to c): Our evaluation of previous epochs of GLO and its pro and con drivers clearly shows that GLO is not an ever-growing, irreversible, linear, self-sustainable, long-term trend, but has in-built oscillations. Physical GLO is now receding, but the digital one, or science cooperation, is growing. Oscillations in GLO have mostly been the result of internal causes. The outcome of such ambivalent factors depends on the trade-offs made, the strengths of the external and internal factors, the context, and our policies/ attitudes (GLO and de-GLO are man-made!) containing negative or promoting positive GLO/de-GLO drivers. The opinions of publics along with the interests and the stakes involved ${ }^{32}$ also play an important role. The question is not either/or, but which kind and how much of GLO and de-GLO do we want to have or is optimal in the long run. We have experienced de-GLO periods in the past and also will in the future. Yes, the current type of (hyper)GLO

32 If Google and Science Direct are any indication, de-GLO is now winning in the sense of interests of scientists the public ( 7.03 million hits compared to 2.6 million for GLO). About 10 years ago, according to Mencinger (2010) the results were quite different (just 9 articles in the best economic journals on de-GLO but 19,842 on GLO). Even worse is the situation while comparing hits for "pandemic" today or 10 years ago; almost no interest 10 years ago and 372 million hits today. 
is at risk, but "the fundamental rationales for globalization have not eroded" (Contractor, 2021). GLO is here to stay, provided that it transforms towards GLO that is fairer and adequately compensates the losers of free trade/GLO. The long-term, well-rooted factors driving GLO can outperform the factors opposing GLO. The pandemic has shown that de-GLO is no solution, nor is leaving hyper GLO unchanged. The final outcome of such divergent trends will probably be the coexistence of GLO and de-GLO. More GLO in some sectors like the flow of information, research cooperation, governance, virtualisation of communications, coordination in health sector and, in contrast, we will also see de-GLO tendencies like the slowing down of trade (less FDI), eliminating certain unnecessary trade flows, bringing some production back home (reindustrialisation) as an element of restructuring GVCs, the "nationalisation' of the production of health products, medicines (vaccine nationalism) as part of stronger economic nationalism. "The world of tomorrow is not likely to stop being globalized, interconnected and interdependent" (Morillas, 2020). "Like the slime mold, human society will need to continually vacillate between globalisation and de globalisation, seeking that elusive balance, as we strive to live more securely both with nature and ourselves" (Pross, 2020: 906), because new waves of infections are certainly coming.

In relation to d): The trade-off between GLO as a constructive and destructive force, between GLO/de-GLO and the pandemic, depends greatly on the context - the zeitgeist. The context has structurally changed compared to any previous GLO periods. All such deeply-rooted tendencies and factors are working today in a completely new global context of changing power relationships. The hegemonic decline of the USA could, as predicted by the realist school, lead to de-GLO, yet the redistribution of power occurring so soon and being so dramatically altered was not as some predicted. The pandemic will probably accelerate the changes already underway, towards a more China-centric GLO and concert of nations ${ }^{33}$ type of polycentric multilateral system. China might emerge from this as a relative winner. We may agree with Rodrik that:

COVID-19 may well not alter - much less reverse - tendencies evident before the crisis. Neoliberalism will continue its slow death. Populist autocrats will become even more authoritarian. Hyper-globalization will remain on the defensive as nation-states reclaim policy space. China and the US will continue on their collision course. And the battle within nation-states among oligarchs, authoritarian populists, and liberal internationalists will intensify, while the left struggles to devise a program that appeals to a majority of voters. (Rodrik, 2020a)

33 Haass and Kupchan, 2021. 
The VUCA world has not only changed business but the political environment, our attitudes and priorities as well. Security and resilience have grown in importance in an ever more digitalised, yet also more vulnerable world (cybercrime). The Covid-19 pandemic has acted as a catalyst for digitalisation of the economy and thereby implicitly stimulated GLO. While digital solutions have no borders, they also come with limits, both technological and social.

In relation to e): Big causes, like wars, crises, have always had big, unforeseen effects. After WWI, the League of Nations was established to preserve world peace and prevent the bad experiences with the GD. WWII gave birth to the United Nations Organisation and the New Deal in the USA. Hopefully, the pandemic is giving an opportunity for radical changes, provided that it is not business as usual, like what occurred following the GR. The pandemic has already produced strong impacts on our way of life, on our social attitudes, adding to the chances of using it as a moment for a "critical reflection on our way of life, our type of civilisation, our social order (system ${ }^{34}$ ) which have all led us to such an apocalyptical crisis" (personal note by Rizman).

Mencinger (2010) was probably right when saying that:

rapid de-globalization and market closure would lead to economic catastrophe, especially in small economies depending so much on trade and addicted to FDI. However, gradual abandoning the belief that globalization brings prosperity to all, and ending efforts to regulate the economy globally, would make the world friendlier; social responsibility can only be local and not global. Global GDP growth would probably be lower, and many services that belong to the group of 'taking off your shoes at airports' (by definition it increases GDP), might disappear. But the problem of the world is not too little product and wealth; there is too much of both. The problem is the distribution of it, the problem of the world is not creating enough goods, but creating enough work. And yet: a less global world will be more diverse, more stable and less boring.

\section{BIBLIOGRAPHY}

Autor, David, David Dorn and Gordon H. Hanson (2013): The China Syndrome: Local Labour Market Effects of Import Competition in the United States. American Economic Review 103 (6): 2121-2168.

Bauer, Joachim (2008): Princip človeškosti. Študenska založba, Ljubljana. Beck, Ulrich (1999): World Risk Society, Cambridge: Polity Press.

Beck, U., S. Lash and B. Wynne (1992): Risk Society: Towards a New Modernity (17). Sage.

34 For more on systemic changes, Svetličič, 2021. 
Bergeijk, van Peter A. G. (2018): On the Brink of Deglobalisation... Again. Cambridge Journal of Regions, Economy and Society 2018 (11): 59-72.

Boyacigiller, Nakiye A. and Nancy Adler (1991): The Parochial Dinosaur: Organizational Science in a Global Context. The Academy of Management Review 16 (2): 262-290.

Bordo, Michael D., Alan M. Taylor and Jeffrey G. Williamson (eds) (2003): GLO in Historical Perspective. Chicago and London: University of Chicago Press.

Bordo, Michael (2017): The Second Era of Glo is Not Yet Over: An Historical Perspective. Michael D. Bordo Working Paper 23786. Accessible at http://www. Nber.Org/Papers/W23786 National Bureau of Economic Research, 10. 12. 2020.

Bourguignon, François, Diane Coyle, Raquel Fernández, Francesco Giavazzi, Dalia Marin, Kevin O'Rourke, Trinity College, Dublin and CEPR Richard Portes, Paul Seabright, Anthony Venables, Thierry Verdier, Alan Winters (2002): Making Sense of Globalization. A Guide to the Economic Issues CEPR Policy Paper No. 8.

Buckley, Peter (2020): The Theory and Empirics of the Structural Reshaping of Globalization. Journal of International Business Studies 51 (9): 1580-1592.

Churchman, C. West (1967): Editorial: Wicked Problems. Management Science 14 (4): B-141.

Contractor, Farok J. (2021): The World Economy Will Need Even More Globalization in the Post-Pandemic 2021 Decade. Journal of International Business Studies (2021), Academy of International Business.

De Grauwe, Paul (2016): How far should we push globalisation? Accessible at https://www.socialeurope.eu/far-push-globalisation, 14. 12. 2019.

Eden, Lorraine and M. Fernanda Wagstaff (2020): Evidence-based Policymaking and the Wicked Problem of SDG 5 Gender Equality. Journal of International Business Policy. Accessible at Eden-Wagstaff2020_Article_Evidence-based PolicymakingAndT.pdf, 10. 12. 2020.

Farrell, Henry and Abraham Newman (2020): Will Coronavirus End Globalization as We Know It? Accessible at Will the Coronavirus End Globalization as We Know It? | Foreign Affairs, 6. 1. 2021.

Farzanegan, Mohammad Reza and Mehdi Feizi and Hassan F. Gholipour (2020): Globalization and Outbreak of COVID-19: An Empirical Analysis (2020). CESifo Working Paper No. 8315. Accessible at https://ssrn.com/abstract=3618839, 12. 12. 2020.

Ferguson, Niall (2002): Full Marx. Financial Times, 16 August 2002. Accessible at http://www3.amherst.edu/ pmachala/Current\%20Politics/PS-81-miscellane ous/Readings\%20for\%20the\%20First\%20Class/Ferguson,\%20Full\%20Marx, 20. 11. 2020.

Findlay, Ronald and Kevin H. O'Rourke (1997): Power and Plenty: Trade, War, and the World Economy in the Second Millennium. New Jersey: Princeton University Press.

Fukuyama, Francis (2020): The Pandemic and Political Order; It Takes a State. Accessible at Francis Fukuyama on the Pandemic and Political Order (foreignaffairs.com), 5. 1. 2021. 
Friedman, Thomas (2014): Stampeding Black Elephants. New York Times, 22. 11. 2021.

Haass, Richard (2020): Why Global Issues Matter. Accessible at https://www.mckinsey.com/featured-insights/leadership/james-manyika-speaks-with-richardhaass-about-businesses-as-global-entities? cid=other-eml-alt-mip-mck\&hdpid =16 66c41c-27f8-43ea-9aae-f27f29c4bfd2\&hctky=2110282\&hlkid=6ad657ea65da419 4b2b358bc395d2cb6, 5. 12. 2020.

Haass, Richard N. and Charles A. Kupchan (2021): How to Prevent Catastrophe and Promote Stability in a Multipolar World, March 23. Accessible at The New Concert of Powers | Foreign Affairs, 15. 4. 2021.

Harper, Kyle (2020): The Coronavirus Is Accelerating History Past the Breaking Point. Accessible at https://foreignpolicy.com/2020/04/06/coronavirusisaccelerating-history-past-the-breaking-point/?utm_source=PostUpandutm_ medium=emailandutm_campaign=20802andutm_term=Editors\%20Picks $\% 20$ OCand?tpcc=20802, 26. 5. 2020.

Hillebrand, Evan E. (2002): Deglobalization Scenarios: Who Wins? Who Loses? Accessible at http://www.uky.edu/ ehill2/dynpage_upload/files/DeglobalizationScenarios.pdf, 2. 3. 2020.

IMF, World Economic Outlook (2007): Spillovers and Cycles in the Global Economy. James, Harold (2002): The End of Globalization; Lessons from the Great Depression. Harvard University Press.

Kardelj, Edvard (1979): The Historical Roots of Non-alignment. Belgrade: STP.

Keynes, Maynard (1933): National Self-Sufficiency. The Yale Review 22 (4): 755769.

Kindleberger, Charles (1989): Manias, Panics and Crashes: A History of Financial Crises. New York: Basic Books.

Kobrin, Stephen J. (2017): Bricks and Mortar in a Borderless World: Globalization, the Backlash, and the Multinational Enterprise. Global Strategy Journal 7: 159171.

Kondratieff, Nikolai (1935): The Long Waves in Economic Life. Review of Economic Statistics 17 (6): 105-115.

Lakner-Milanovic (2013): Global Income Distribution: From the Fall of the Berlin Wall to the Great Recession. Accessible at https://openknowledge.worldbank. org/handle/10986/16935, 2. 5. 2018.

Lamy, Pascal, (2020): Is Globalization Doomed? Accessible at https://progressivepost.eu/no-category/is-globalisation-doomed, Sept.10.2020, 6. 1. 2021.

Mazzucato, Mariana (2020): Capitalism's Triple Crisis, Project-Syndicate. Accessible at https://www.project-syndicate.org/commentary/covid19-crises-of-capitalismnew-state-role-by-mariana-mazzucato-2020-03, 13. 6. 2020.

Mahbubani, Kishore 2020): Has China Won? The Chinese Challenge to American Primacy. New York: Hachette Book Group. Economics, WP 04-2.

Marx, Karl and Friedrich Engels (2006/1928): Communist Manifesto. Published Online by Socialist Labor Party of America, accessible at www.slp.org, 2. 4. 2021.

Mendoza, Ronald U., Arsenio M. Balisacan, Sheena Valenzuela and Geoffrey Ducanes (2021): Navigating Globalization in the Aftermath of COVID-19. 
Accessible at (7) (PDF) Navigating Globalization in the Aftermath of COVID-19 (researchgate.net), 2. 4. 2021.

Milanović, Branko (2020): The Real Pandemic Danger Is Social Collapse. Accessible at As the Pandemic Drives the Global Economy Apart, Societies May Break Apart, Too | Foreign Affairs, 12. 1. 2021.

Morillas, Pol (2020): Lessons from a Global Crisis: Coronavirus, the International Order and the Future of the EU. Accessible at CIDOB - Lessons from a global crisis: coronavirus, the international order and the future of the EU, 12. 1. 2021.

Niblett, Robin (2020): The End of GLO as We Know It. Accessible at How the World Will Look After the Coronavirus Pandemic - Central Tibetan Administration, 3. 4. 2021.

NIC (2021): Global Trends 2040; A More Contested World. National Intelligence Council, USA, March.

Norberg, Johan (2020): Open: The Story of Human Progress. Atlantic Books. Accessible at Norberg: Open: The Story of Human Progress - Human Progress, 9. 12. 2020.

Polanyi, Karl (1975): The Great Transformation. The Political and Economic Origins of Our Time. Boston: Beacon Press.

Pross, Addy (2020): COVID 19, Globalization, De globalization and the Slime Mold's Lessons For Us All 14 May 2020. Accessible at https://onlinelibrary.wiley.com/ doi/epdf/10.1002/ijch.202000042, 5. 10. 2020.

Posen, Adam S. (2020): Rebuilding the Global Economy. Accessible at https://www. piie.com/microsites/rebuilding-global-economy?utm_source=update-news letter\&utm_medium=email\&utm_campaign=piie-insider\&utm_term=2020-1021 12. 12. 2020.

Rašković, Matevž (2021): International Business Policymaking for a Non-Ergodic "Wicked" World. Journal of International Business Policy. Accessible at https:// link.springer.com/content/pdf/10.1057/s42214-021-00113-w.pdf, 27. 8. 2021.

Rizman, Rudi (2008): Globalizacija in avtonomija. Filozofska fakulteta, Ljubljana.

Rodrik, Dani (2011): The Globalization Paradox. New York: W.W. Norton \& Company.

Rodrik, Dani: (2020a): Will COVID-19 Remake the World? Project Syndicate, April 6 Accessible at Dani Rodrik: Will COVID-19 Remake the World? I IWM, 1. 10. 2021.

Roubini, Nouriel and Stephen Mihm (2010): Crises Economics. New York: Penguin Press.

Schumpeter, Joseph, (1934): The Theory of Economic Development. Cambridge, MA: Harvard University Press.

Smith, Adam (1776/1991): An Enquiry into the Nature and Causes of the Wealth of Nations, 2 Vols., edited by Campbell, R. H. and A. S. Skinner. Oxford: Oxford University Press.

Svetličič, Marjan (1997): Pravi pasti globalizacije sta provincializem in neznanje: knjigi Pasti globalizacije na rob. Teorija in praksa 34 (4): 596-608.

Svetličič, Marjan (2000): Globalization: Neither Hell nor Paradise. Journal of International Relations and Development 3 (4). 
Svetličič, Marjan (2020): China in the World Economy and its Economic Relations with Slovenia: Past, Present and the Future. Ljubljana: CMO, FDV.

Svetličič, Marjan (2021): Searching for a Real New Normal. Družboslovne razprave, forthcoming.

Williamson, Jeffrey (2002): Winners and Losers Over Two Centuries of Globalization, Cambridge, MA: National Bureau of Economic Research Working Paper 9161.

Witt, Michael A. (2019): De-globalization: Theories, Predictions, and Opportunities for International Business Research. Journal of International Business Studies 50 (7): 1053-1077.

Zelizer, V. A. (1999): Multiple Markets: Multiple Cultures. In NJ (ed.), Diversity and Its Discontents: Cultural Conflict and Common Ground in Contemporary American Society.

Young, Jason (2020): China, Covid-19 and the end of globalisation as we knew it. MSN Newsroom, April 10. Accessible at https://www.msn.com/en-nz/news/ other/china-covid-19-and-the-end-ofglobalisation-as-we-knew-it/ar-BB12s5Vp, 12. 12. 2010.

\section{SOURCES}

Mencinger, Jože (2010): Deglobalizacija, Mladina 10. 7. 2020. Deglobalizacija | MLADINA.si.

Rodrik, Dani (2020b): The Best Books on Globalisation recommended by Dani Rodrik. Interview by Sophie Roell. Accessible at The Best Books on Globalisation | Five Books Expert Recommendations, 11. 11. 2020.

The Economist (2020, Dec. 19): Free exchange; Location, Location, Location, 100.

UNCTAD (2013): World Investment Report 2013: Global Value Chains: Investment and Trade for Development. New York: United Nations.

UN Economist Network for the UN 75th Anniversary (2020): Shaping the Trends of Our Time. Accessible at 20-124-unen-75report-full-en-revised.pdf. 12. 1. 2021.

Van de Pas, Remco, (2020): Globalization Paradox and the Coronavirus Pandemic. Clingendael Report May 2020. Accessible at https://www.clingendael.org/sites /default/files/2020-05/Report_Globalization_Paradox_and_Coronavirus_ Pandemic_May_2020.pdf, 9.9.2020. 